\title{
EVALUATING THE BENEFITS OF THE OLD AND THE NEW PENSION SCHEMES IN NIGERIA
}

\author{
Mathew Olasehinde Fashagba ${ }^{1 *}$ and Emmanuel Olaniyi Dunmade ${ }^{2}$ \\ I'brahim Badamasi Babangida University, Lapai, Niger State, Nigeria \\ ${ }^{2}$ Faculty of Management Sciences, University of Ilorin, Ilorin, Nigeria
}

This study is aimed at examining the difference between the retirement benefit of the old, pay-as-yougo pension scheme, and the new, contributory pension scheme (CPS). The data used in the study were obtained indirectly from secondary sources. In the study, the Analysis of Variance (ANOVA) and the Pearson Correlation methods are employed, aided by the SPSS for the purpose of data analysis. The study finds that the financial value of the retirement benefit of the old pension scheme is significantly higher than that of the new pension scheme. The study also finds that the benefits of the two pension schemes significantly follow the same trend. The study concludes that the new pension scheme pays out a lesser amount of the retirement benefit than the old. The study provides the recommendations for the efficient management of the investments in the pension fund so as to achieve a sufficient return in order to bridge the gap with respect to the retirement benefit between the two pension plans.

Keywords: retirement benefit, defined benefit, defined contribution, retirement income

JEL Classification: M21, G20

\section{INTRODUCTION}

A pension is the retirement benefit offered to elderly employees by the employer or by the organization that they worked for after the former was disengaged from the service by the latter, on certain merits. The major goal of a pension is to ensure that the retiree's source of living does not end at retirement. N. Barr and P. Diamond (2006) are of the opinion that the purpose of a pension is to allow consumption to

* Correspondence to: M. O. Fashagba, Ibrahim Badamasi Babangida University, P. M. B. 11, Lapai, Niger State, Nigeria; e-mail:mfashagba@yahoo.com continue beyond one's work-life. A pension provides one with the means for continuous income, as well as consumption, during retirement.

The pension system was introduced in Nigeria by the former colonial master in 1951, for European workers and with a retrospective effect back in January 1946 (Odia \& Okoye, 2012). The act was referred to as the pension ordinance and became the origin of a modern pension in Nigeria and the first pension law in the history of the country.

From the inception of the pension in Nigeria, the Pay-As-You-Go (PAYG) scheme, a form of the defined 
benefit (DB), was adopted as the common pension practiced throughout the nations of the world and more specifically operated by the British, her colonial Master, at that time, and substantively practiced till June 2004. Although the PAYG pension scheme had remained the official pension practice in the country since 1951 only with a minor adjustment as was considered to be appropriate from time to time, it was not until 2004 that the first major reform of the pension system was being undertaken in Nigeria, thereby leading to a change in the pension system from the pay-as-you-go to the contributory pension scheme, a form of the defined contribution (DC) pension scheme.

Like many other countries, including Chile and Taiwan, Nigeria followed the form of the defined contribution pension scheme model recommended by the World Bank and adopted the contributory pension scheme following her major pension reform generally referred to as the 2004 Pension Reform Act. According to J. O. Odia and A. E. Okoye (2012), many countries opted for the various forms of the contributory pension scheme. C. W. Peifer (2015) noted that there had been a steady decline in the employer sponsor pension plan over several decades. M. I. Orenstein (2008) identified some of the countries that had changed their pension systems from the defined benefit pension scheme to the defined contribution pension, including Chile in 1981, Bolivia in 1997, Mexico in 1997, Nigeria in 2004, and so on. The arguments for replacing the old pension scheme with the new pension scheme across the nations of the world are, among other things, also inclusive of, but not limited to a reduction in fertility, the improvement of the healthcare system and a subsequent reduction in the labor force. The consequence of the improvement of the health facility reflected in an increase in the lifespan of the old retiree (Meng \& Pfan, 2010; Lachman, 2013). The implication of the expansion of the retiree's lifespan is that more funds will be required so as to be able to pay an increased number of the old due to the improved health facility. At the same time, fewer workers are available for production for the sustenance of both the current employees themselves and the old, retirees, who did not provide for their retirement. This was captured in M. O. Fashagba (2018), stating that the defined benefit scheme requires a growing working population to succeed.

Thus, the need for the replacement of the pay-as-yougo with the contributory pension scheme became necessary. In addition to the foregoing universal factors, there are local problems peculiar to the defined benefit pension in Nigeria. According to J. A. Oladipo and M. O. Fashagba (2012), J. O. Odia and A. E. Okoye (2012), these problems of the old pension scheme in Nigeria include the nonpayment or a delay in the payment of the pension benefit as and when due, a huge pension debt of about N2.06 billion as of December 2005, the rigorous processes involved prior to the pension payment, and a poor record of pensioners and so forth. T. A. Fapohunda (2013) summarized the problems of the old pension scheme in Nigeria as inadequate funding, an inadequate subvention and grant, and poor documentation.

The replacement of the old scheme as at the time was evidently justified since it was no longer capable of meeting the goal of the pension scheme, which is to provide regular income to the retiree as and when due from the time of retirement. However, a worthy replacement should be expected to answer the many questions the old scheme was no longer able to give answers to. Transition from the old pension scheme to the new contributory pension scheme in Nigeria in 2004, with about fourteen years of the implementation of the new scheme, is justifiably due for evaluation. The subject matter of this study is to measure and compare the financial value of the retirement benefit of the old pension scheme and that of the new in Nigeria.

The main objective of the study is to evaluate the difference in the retirement benefit between the new pension scheme and the old pension scheme in Nigeria. The specific objectives are to determine if the new pension scheme provides a better retirement benefit than the old pension scheme did in Nigeria, and also to determine if the benefits of the new scheme and the old pension benefit follow the same trends. 
The hypotheses of the study are stated in the null form as follows:

H1: The retirement benefit of the Contributory Pension Scheme is not significantly different from the retirement benefit under the defined benefit plan in Nigeria.

H2: There is no significant difference in the pension benefit trend between the defined pension benefit scheme and the contributory pension scheme in Nigeria.

The first and the second hypotheses of the study are analyzed by applying the ANOVA and Pearson Correlation methods, respectively. The two tests of the hypotheses are performed at a $95 \%$ confidence level.

The study is structured into five sections. This, first section is the introduction to the study. In the next section, the relevant literature is reviewed. The third section presents a discussion over the methodology applied in the study. The data analysis and the discussion of the findings are contained in the fourth section. The final section is the conclusion of the study.

\section{LITERATURE REVIEW}

This section of the study consists of a literature review. It is important to note that, while there are abundant studies on pension funds investment, investment return, etc. (Munnell, Aubry \& Crawford, 2015), to the authors' best knowledge there is no existing work on the comparison of the retirement benefit between the pay-as-you-go and the contributory pension schemes; hence, it is difficult to include empirical issues in this section.

\section{Importance of Pension}

The roles of a pension will be classified in the study into two classes, namely the primary role, arising from the main objective of insurance, on the one hand, and the secondary roles that arise from the functions created by the existent pension.
The primary role of a pension is the provision of retirement income. A pension provides income for the old, who is unable to work again (Kibet \& Simiyu, 2016). A pension serves as a medium for saving towards future income when the employee's normal life can no longer be sustained.

The secondary roles of a pension are derived from the pension funds created by saving towards a pension payment. The roles include, among other things, financial intermediation and economic development. Several studies on the relationship between economic growth and pension funds have shown that pension funds have a positive impact on economic growth (Akowe, Ocheni \& Daniel, 2015; Farayibi, 2016).

Pension funds reduce the cost of capital (Davis, 2015). Through pension savings, additional funds are made available to the traditional mediums of institutional saving. By applying the microeconomic theory of the price mechanism, an increase in supply forces down the price. Hence, the cost of capital reduces as more funds are created through pension savings.

Similarly, O. I. Tirimba (2013) observes that pension funds provide less expensive funds for diversification. The existence of pension funds does not only make funds available for investment, but such funds become more affordable and encourage the diversification of the economy.

Finally, pension funds affect economic growth through the provision of additional funds for financing economic activities and stimulate growth. A positive relationship between pension funds and economic growth has been shown in different empirical studies (Edogbanya, 2013; Akowe et al, 2015). Therefore, a pension plays important roles both for individual retirees and for the economy as a whole.

\section{Retirement Benefit}

The term "retirement" is the official disengagement of an employee from the service of an employer. One's age is the major factor taken into consideration when deciding on retiring one from one's job. Retirement means giving up one's job (Eme \& Sam, 2011). At 
a certain age, the employee's physical strength reaches the point of diminishing return, whereby the productive ability is expected to decline, and the retention of the employee in the workplace by the employer becomes no longer profitable. The reasonable thing to do for such an employee at the point where his/her service is no longer profitable is to let such an employee go. The term for the disengagement of an employee from a job after the statutory years of service is known as retirement.

M. Ali (2014) defined retirement as the disengagement of an employee from the regular job.

The retirement benefit is the benefit that the employee still continues to enjoy from the former employer on the merit of his/her having served the employer with his/her strength. Therefore, the retirement benefit is the payment that the employee receives from the employer at retirement (Barbier, 2007). It is the continuation of the regular financial flow from the employer to the employee beyond retirement. The retirement benefit is broadly classified into two major types, namely: gratuity and pension.

\section{Pension}

According to R. W. Humphrey (1995), the origin of the official pension plan was traced back to 1875 with the American Express Company. The company provided a benefit for its employees at one-half of the last ten years of the annual pay for the employees at retirement. However, it was not until about 30 years later that a modern pension found its way to Britain, with the Old Age Pension Act of 1905 (OECD, 2008).

A pension is a retirement benefit, unlike gratuity, that provides regular income for the retiree from the time of retirement. Traditionally, a pension has been used as a device to provide sustenance for the old and disengaged employee, who may not be able to work again because of his/her old age. The pension concept has been diversely defined by different authors in different studies. For instance, J. O. Odia and A. E. Okoye (2012) saw a pension as the amount paid by the government or a company to an employee after his/ her having been working for some specific period of time, who is considered to be too old or ill to work or has reached the statutory age of retirement.

T. A. Fapohunda (2013) viewed a pension as a system designed to provide the employee of an organization with a means of securing at retirement a standard of living reasonably, consistent with that enjoyed while in service. These definitions show that a pension has to do with one's age. A pension is a payment to retirees, usually at their old age.

M. O. Fashagba (2018) defined a pension as a post retirement benefit to an old employee after his/her disengagement from active service. Similarly, the Nigerian State Pension Reform Law (2015) explained that a pension is a deferred salary paid during a worker's retirement. In other words, a pension is an extension of a salary to the old when the employee is no longer in service because of his/her age or due to the death of the employee's spouse.

C. J. Nwanegbo (2007) held that a pension is a monthly payment to the old, retired, widowed and disabled.

A. Neil (1977) defined a pension as a retirement provided by the employer to the employee on the condition of retirement, age and ill health. This definition also implies that a pension payment is conditional upon old age, ill health or death.

Depending on the form of the pension plan, the retirement benefit either in the form of a gratuity or a pension depends on the years of service. For instance, the 1992 Nigerian Pension Law requires five (5) years of service to qualify for a gratuity and ten (10) years of service for a pension (Ali, 2014).

There are two broad pension plans for pension administration. They are the defined benefit pension plan and the defined contribution pension plan. The two are briefly reviewed as follows:

\section{Defined Benefit Pension Plan (DB)}

Conventionally, the pension benefit has been paid with the defined benefit (DB) pension plan. The defined benefit pays the retiree a monthly pension from retirement to the moment of death by using the 
number of the years of service and the salary (Curtin, 2009). In addition, C. W. Peifer (2015) opined that the present value of the future pension payment of an employee could be estimated on the four assumptions that include the number of the years of service, the salary, the employee's retirement lifespan and a pension investment gain (where the investment of a pension asset exists). In the Defined Benefit Plan, the sponsoring firm bears the risk of the pension funding, as well as that of the management of the investment. According to J. Broadbent, M. Palumbo and E. Woodman (2006), the basic features of the defined plan include the following:

- the plan promises the employee a monthly pension payment from the date of his/her retirement to the date of his/her death or even still to the date of the death of the employee's spouse;

- the plan usually promises that the formula for calculating the amount of a monthly pension to be paid to the employee shall be that including the years of service with the sponsoring firm as the basis of the computation; hence, the amount of the pension can be predetermined in advance;

- the pension is earned as per each year of service; the percentage of the earning of each year of service with the sponsoring firm is what determines the amount of the monthly pension the employee is entitled to from the date of retirement.

Workers mobility is discouraged in order to avoid a loss of an accrual pension with a change in employment, thus enhancing labor stability.

\section{Defined Contribution Pension Plan (DC)}

The Defined Contribution Pension Plan has significantly grown since it appeared for the first time (Curtin, 2009). The plan does not apply any formula for the amount of a monthly pension payment, but rather uses the accumulated fund in the employee's retirement savings account (RSA) at the time of retirement. The employer and/or the employee contribute a percentage of the employee's monthly emolument to the employee's retirement benefit fund.
Also, under the defined contribution pension plan, the employee bears more of the risk associated with the pension fund (Broadbent et al, 2006). Unlike the defined benefit pension plan, the risk of the pension fund and the management of investments in it are shifted to the employee.

There has been a tremendous shift from the defined benefit pension plan to the defined contribution pension plan in the last few decades. For example, H. Blommestein, P. Janssen, N. Kortleve and J. Yermo (2009) observed that employers were increasingly turning to the defined contribution where the employee bore the entire income risk. Also, J. Poterba, J. Rauh, S. Venti and D. Wise (2007) noted that the retirement arrangements of the private sector in the United States that were predominantly the defined benefit had shifted to the defined contribution in the previous two decades, leaving only the public in the defined benefit pension plan. The features of the defined contribution pension plan include the following:

- the defined contribution pension plan provides for a personal individual employee retirement savings account to the employee;

- deriving from the first point mentioned above, the defined contribution pension plan allows room for workers mobility as the fear of an accrual loss for the years of service put into a job is completely eliminated;

- the defined contribution pension plan does not provide for the knowledge of the amount of a monthly pension in advance.

\section{RESEARCH METHODOLOGY}

The objective of this study is to determine the effect of the change in the pension scheme from the defined benefit plan to the defined contribution plan on the retirement benefit in Nigeria. The research data were obtained from secondary sources. The use of the secondary data is justified as the primary data cannot be obtained for the purpose of the study. 
The secondary data available and collected for conducting the study were not in the form of the data ready for the purpose of the analysis carried out in this study, for which reason the data were further processed into the form allowing their use in the analysis conducted in this study. The independent variable in the study is the pension benefit for the contributory pension scheme in Nigeria. It was derived by applying the accumulated value function at a $5 \%$ interest rate for $18 \%$ of the employee's emolument for the period of service of 5 to 35 years. The dependent variable is the retirement benefit from the defined benefit in Nigeria. The present value of the retirement benefit for all the years of retirement (assuming that pension payments continue for 30 years) at $5 \%$ by using the defined benefit plan provided in the 1992 Pension Law in Nigeria. The data analysis methods applied in this study are the Analysis of Variance (ANOVA) and the Pearson Correlation methods, aided by the SPSS version. The ANOVA method was used in order to analyze the first hypothesis, whereas the Pearson Correlation method was used in order to test the second hypothesis. The use of the concerned methods is justified for the reason of their suitability for the nature of the data analyzed in the study. Also, ANOVA is an efficient method for the comparison of the means of different samples.

\section{DATA PRESENTATION AND ANALYSIS}

The data used in the study are the percentage of the final salary used for a gratuity and pension in the 1992 Pension Law in Nigeria and the percentage of the employee's emoluments jointly contributed by the employer and the employee to the employee retirement savings account, as is envisaged by the 2004 Pension Reform Act in Federal Republic of Nigeria (2004; 2014). The final salary percentage of the retirement benefit is presented in Table 1.
Table 1 The retirement benefit percentages based on the years of service

\begin{tabular}{|c|c|c|}
\hline $\begin{array}{l}\text { Years of } \\
\text { Qualifying } \\
\text { Service }\end{array}$ & $\begin{array}{l}\text { Gratuity as the } \\
\text { percentage } \\
\text { of the final } \\
\text { emolument }\end{array}$ & $\begin{array}{l}\text { Pension as the } \\
\text { percentage of } \\
\text { the final total } \\
\text { emolument }\end{array}$ \\
\hline 5 & 100 & - \\
\hline 6 & 108 & - \\
\hline 7 & 116 & - \\
\hline 8 & 124 & - \\
\hline 9 & 132 & - \\
\hline 10 & 100 & 30 \\
\hline 11 & 108 & 32 \\
\hline 12 & 116 & 34 \\
\hline 13 & 124 & 36 \\
\hline 14 & 132 & 38 \\
\hline 15 & 140 & 40 \\
\hline 16 & 148 & 42 \\
\hline 17 & 156 & 44 \\
\hline 18 & 164 & 46 \\
\hline 19 & 172 & 48 \\
\hline 20 & 180 & 50 \\
\hline 21 & 188 & 52 \\
\hline 22 & 196 & 54 \\
\hline 23 & 204 & 56 \\
\hline 24 & 212 & 58 \\
\hline 25 & 220 & 60 \\
\hline 26 & 228 & 62 \\
\hline 27 & 236 & 64 \\
\hline 28 & 244 & 66 \\
\hline 29 & 252 & 68 \\
\hline 30 & 260 & 70 \\
\hline 31 & 268 & 72 \\
\hline 32 & 276 & 74 \\
\hline 33 & 284 & 76 \\
\hline 34 & 292 & 78 \\
\hline 35 & 300 & 80 \\
\hline
\end{tabular}

Source: Ali, 2014

The retirement benefit under the defined benefit plan which consists of the gratuity and the pension in Nigeria can be predetermined by the percentage of the employee's final salary. Given the percentage of any employee, it is possible to know the amount of 
both the gratuity and the pension that the employee will be entitled to based on his/her final salary and the years of service the employee had put into the sponsoring firm, while the retirement benefit under the contributory pension scheme consists of the accumulation of all contributions into the employee's retirement savings account for all the years of service at the prevailing interest rate. The Pension Reform Act in Federal Republic of Nigeria (2004) provides that the total monthly contribution to the employee's retirement savings account is $15 \%$ of the employee's emolument. However, the Pension Reform Act in Federal Republic of Nigeria (2014) reviewed the percentage upwards to $18 \%$, which is the percentage adopted in this study.

Thus, the current value for the employee's total retirement benefit fund at the time of retirement for the employee who earns one naira (\$1) monthly for the period of 5 to 35 years of service is computed at $5 \%$ and is presented in Table 2 . The accumulated formula allows the retirement savings account to be computed as follows:

Monthly salary $=\$ 1$

Annual salary $=\$ 1 \times 12=\$ 12$

Total annual pension contribution $=\mathrm{N} 12 \times 18 \%=\mathrm{N} 2.16$

Accumulated pension contribution at the end of the $n$ years of service

$$
=\$ 2.16 \frac{(1+0.05)-1}{0.05}
$$

where $5 \leq n \leq 35$

On the other hand, the defined benefit provides for both the gratuity and the pension. The sum of the gratuity and the present value of all future pensions give the equivalent of the retirement benefit at the time of retirement according to the contributory pension scheme. This can be computed for the different $n$ years (5 to 35) of service, with the percentages accounted for in Table 1. The 30-year retirement benefit for the defined benefit in Nigeria for the employee with the final salary amounting to one naira for the period (5 to 35 years) of service shown in Table 1 is computed at the same $5 \%$ interest rate as follows:
Retirement benefit $=G+P\left(\frac{1-v^{n}}{i}\right)$

where

$$
\begin{aligned}
& G=\text { Gratuity (the percentage of the final salary) } \\
& P=\text { Annual pension (the percentage of the } \\
& \quad \text { pension on the final annual salary) } \\
& v=\text { Present value }(1 /(1+0.05)) \\
& i=\text { Interest rate }(0.05)
\end{aligned}
$$

The current value for the retirement benefit for both the DBP and the CPS is presented in Table 2.

Table 2 presents the current value of the employee's retirement benefit at the time of the retirement of the employee who earns one naira per month and $\$ 12$ per annum, computed at a $5 \%$ interest rate. The $1^{\text {st }}$ column shows the years of service, the $2^{\text {nd }}$ to the $5^{\text {th }}$ columns demonstrate the retirement benefit for the defined benefit plan in Nigeria, and the $6^{\text {th }}$ and the $7^{\text {th }}$ columns show the retirement benefit for the contributory pension scheme. The gratuity for each year of service is presented in the $2^{\text {nd }}$ column. The annual pension is presented in the $3^{\text {rd }}$ column. The present value of the 30 -year annual pension is presented in the $4^{\text {th }}$ column, and the $5^{\text {th }}$ column shows the addition of the gratuity in the $2^{\text {nd }}$ column and the present value of the annual pension in the $5^{\text {th }}$ column.

\section{The Test of the Hypotheses}

The two hypotheses stated in the study are evaluated in this section. The analysis of the hypotheses by applying the appropriate methods of analysis is presented below.

The method of the analysis used to test the study is the Analysis of Variance (ANOVA). The result of the analysis is given in Table 3 and Table 4. 
Table 2 The computed current value for the retirement benefit for 5 to 35 years of service for both the DBP and the CPS in Nigeria for the monthly salary of $\$ 1$

\begin{tabular}{|c|c|c|c|c|c|c|}
\hline \multicolumn{5}{|c|}{ Current Benefit Value for Defined Benefit Scheme } & \multicolumn{2}{|c|}{$\begin{array}{l}\text { Current Benefit Value for } \\
\text { Contributory Pension Scheme }\end{array}$} \\
\hline Years (n) & Gratuity & $\begin{array}{l}\text { Annual } \\
\text { pension }\end{array}$ & $\begin{array}{c}\text { Current value } \\
\text { for a 30-year } \\
\text { pension }\end{array}$ & $\begin{array}{l}\text { Total current } \\
\text { value for the } \\
\text { retirement } \\
\text { benefit }(\mathrm{An})\end{array}$ & $\begin{array}{c}\text { Annual } \\
\text { contribution } \\
\text { (18\% of } 12)\end{array}$ & $\begin{array}{c}\text { Current } \\
\text { Value for all } \\
\text { contributions at } \\
\text { retirement (Sn) }\end{array}$ \\
\hline 5 & 12 & - & - & 12 & 2.16 & 11.94 \\
\hline 6 & 12.96 & - & - & 12.96 & 2.16 & 14.69 \\
\hline 7 & 13.92 & - & - & 13.92 & 2.16 & 17.99 \\
\hline 8 & 14.88 & - & - & 14.88 & 2.16 & 20.63 \\
\hline 9 & 15.84 & - & - & 15.84 & 2.16 & 23.82 \\
\hline 10 & 12 & 3.60 & $55 \cdot 34$ & 67.34 & 2.16 & 27.17 \\
\hline 11 & 12.96 & 3.84 & 59.63 & 71.99 & 2.16 & 30.67 \\
\hline 12 & 13.92 & 4.08 & 62.72 & 76.64 & 2.16 & 34.38 \\
\hline 13 & 14.88 & 4.32 & 66.41 & 81.29 & 2.16 & 38.26 \\
\hline 14 & 15.84 & 4.56 & 70.10 & 85.94 & 2.16 & 42.33 \\
\hline 15 & 16.8 & 4.80 & 73.79 & 90.59 & 2.16 & 46.6 \\
\hline 16 & 17.76 & 5.04 & 77.47 & 95.23 & 2.16 & 51.1 \\
\hline 17 & 18.72 & 5.28 & 81.16 & 99.88 & 2.16 & 55.82 \\
\hline 18 & 19.68 & 5.52 & 84.85 & 104.53 & 2.16 & 60.77 \\
\hline 19 & 20.64 & 5.76 & 88.54 & 109.18 & 2.16 & 65.96 \\
\hline 20 & 21.6 & 6.00 & 92.23 & 113.83 & 2.16 & 71.42 \\
\hline 21 & 22.56 & 6.24 & 95.92 & 118.48 & 2.16 & 77.15 \\
\hline 22 & 23.52 & 6.48 & 99.61 & 123.13 & 2.16 & 83.17 \\
\hline 23 & 24.48 & 6.72 & 103.30 & 127.78 & 2.16 & 89.49 \\
\hline 24 & 25.44 & 6.96 & 106.99 & 132.43 & 2.16 & 96.12 \\
\hline 25 & 26.4 & 7.20 & 110.68 & 137.09 & 2.16 & 103.09 \\
\hline 26 & 27.36 & 7.44 & 114.37 & 141.73 & 2.16 & 110.41 \\
\hline 27 & 27.84 & 7.68 & 118.06 & 146.38 & 2.16 & 118.09 \\
\hline 28 & 29.28 & 7.92 & 121.75 & 151.68 & 2.16 & 126.15 \\
\hline 29 & 30.24 & 8.16 & 125.44 & 155.68 & 2.16 & 134.62 \\
\hline 30 & 31.2 & 8.40 & 129.12 & 160.32 & 2.16 & 143.51 \\
\hline 31 & 32.16 & 8.64 & 132.81 & 164.97 & 2.16 & 152.84 \\
\hline 32 & 33.12 & 8.88 & 136.50 & 169.62 & 2.16 & 162.65 \\
\hline 33 & 34.08 & 9.12 & 140.19 & 174.23 & 2.16 & 172.94 \\
\hline 34 & 35.04 & 9.36 & 143.88 & 178.92 & 2.16 & 183.74 \\
\hline 35 & 36 & 9.60 & 147.57 & 183.57 & 2.16 & 195.09 \\
\hline
\end{tabular}

Source: Authors 
Table 3 The model summary

\begin{tabular}{ccccc}
\hline Model & R & R Square & $\begin{array}{c}\text { Adjusted } \\
\text { R Square }\end{array}$ & $\begin{array}{c}\text { Std. Error } \\
\text { of the } \\
\text { Estimate }\end{array}$ \\
\hline 1 & $.931 \mathrm{a}$ & .867 & .863 & 19.57921 \\
\hline
\end{tabular}

a. Predictors: (Constant), Defined contribution

Retirement benefit current value

Source: Authors

The result of the regression presented in Table 3 shows the value of the $\mathrm{R}$ square and the standard error of the analysis to be 0.86 and 195.68, respectively. The ANOVA result is given in Table 4:

Table 4 ANOVA $^{a}$

\begin{tabular}{c|ccccc}
\hline Model & $\begin{array}{c}\text { Sum of } \\
\text { Squares }\end{array}$ & Df & $\begin{array}{c}\text { Mean } \\
\text { Square }\end{array}$ & F & Sig. \\
\hline Regression & 72724.220 & 1 & 72724.220 & 189.709 & $.000^{\mathrm{b}}$ \\
1 Residual & 11117.015 & 29 & 383.345 & & \\
Total & 83841.235 & 30 & & & \\
\hline
\end{tabular}

a. Dependent variable: Defined benefit retirement benefit current value

b. Predictors: (Constant), defined contribution retirement benefit current value

Source: Authors

The result of the ANOVA method applied presented in Table 4 shows that the F value is 189.709 and the significant value is 0.000 . These results show that there is a significant difference between the two pension plans.

The result of the analysis presented in Table 4 provides the statistical evidence of the significant difference between the two pension plans. The null hypothesis is therefore rejected for the alternative hypothesis. The significant value of the test at 0.000 indicates that there is a significant difference between the two pension plans at the 5\% significance level. The implication of the result of the study is that, statistically, the retirement benefit under the old, defined benefit in Nigeria is significantly better than that of the present contributory pension scheme. These results statistically indicate a better retirement benefit value of the defined benefit plan than that of the defined contribution pension plan. This is not in agreement with the rapid change from the defined benefit to the defined contribution pension plan noted in J. Broadbent et al (2006), S. E. Curtinn (2009) and H. Blommestein et al (2009). This change from the DB pension plans to the DC pension plans is not motivated by the value retirement benefit of the pension benefit plans, but rather depends on the merits of the other features of the plans, such as the transfer of the risk pension income burden by the employer.

The method of analysis used to test the second hypothesis is linear regression analysis. The result of the analysis is presented in Table 5.

Table 5 The Pearson correlation of PAUG and CPS

\begin{tabular}{cc|cc}
\hline & DBPS & DCPS & \\
\hline \multirow{2}{*}{ DBPS } & $\begin{array}{c}\text { Pearson } \\
\text { Correlation }\end{array}$ & 1 & $.931^{* *}$ \\
& Sig. (2-tailed) & & .000 \\
& $\mathrm{~N}$ & 31 & 31 \\
\hline \multirow{2}{*}{ DCPS } & Pearson & $.931^{* *}$ & 1 \\
& Correlation & .90 & \\
& Sig. (2-tailed) & .000 & \\
& $\mathrm{~N}$ & 31 & 31 \\
\hline
\end{tabular}

** Correlation is significant at the 0.01 level (2-tailed).

\section{Source: Authors}

The result of data analysis of the second hypothesis is presented in Table 5. The result produces a piece of empirical evidence that the pension amount for the 31year retirement benefit for the two pension schemes follows the same trend. Thus, the null hypothesis is rejected according to the carried-out study. With the value of the Pearson correlation coefficient from the test being 0.93, this result is also shown to be significant at the one percent $(1 \%)$ significance level, with a significant value of 0.000 . In other words, the result of the statistical analysis reveals that the two variables significantly follow the same trend. 


\section{CONCLUSION}

The study evaluated the difference between the retirement benefit of the old pension scheme plan and the new in Nigeria. The data for the study were obtained out of the percentage of the gratuity and the pension for the number of the years of service for the old scheme, such as the percentage of the contribution for the new scheme. The study produced the statistical evidence of a significant difference between the two schemes. Considering the empirical evidence, by making a comparison of the total benefit of the two schemes in Column 5 (the defined pension plan) and in Column 7 (the contributory pension scheme) in the columns in Table 4, the study concludes that the old pension scheme benefit is significantly better than the new scheme in terms of the amount of the pension benefit paid to the retiree. The result showing that the value of the retirement benefit of the old pension scheme is significantly higher than that of the paid pension scheme is the most important result of this study. However, the trend of the retirement benefit for both forms of pension plans for the employee who served for the same number of the years of service is found to be similar.

The major limitation of the study is the fact that the data were indirectly generated given the fact that no direct data were available since the employers of both the private and the public sectors are still gradually changing towards the new scheme. Therefore, a further research study is suggested in the future that will employ direct data since retirees under the new pension scheme are still growing in number in order to be sufficient to provide direct data.

Therefore, the study recommends that efficient management of investments in the pension fund should be put in place so as to be able to achieve sufficient return in order to bridge the gap in the retirement benefit between the pension plans.

\section{REFERENCES}

Ali, M. (2014). Managing post-retirement conditions in Nigeria. Journal of Good Governance and Sustainable Development in Africa, 2(2), 111-121.

Akowe, A., Ocheni, S. I., \& Daniel, A. (2015). Evaluation of the contribution of portfolios of the new contributory pension scheme in Nigeria economy. European Journal of Accounting, Auditing and finance research, 3(10), 1-18.

Barbier, E. B. (2007). Academic Dictionary of Insurance. New Delhi, India: Vikas Publishing House.

Barr, N., \& Diamond, P. (2006). The Economics of Pensions. Oxford Review of Economics Policy, 22(1), 15-39. doi.org/10.1093/oxrep/grj002

Blommestein, H., Janssen, P., Kortleve, N., \& Yermo, J. (2009). Evaluating Risk Sharing In Private Pension Plans. Financial Market trends, OECD

Broadbent, J., Palumbo, M., \& Woodman, E. (2006). The shift from defined benefit to defined contribution pension plan Implication for asset allocation and risk management. Prepared for Working group on institutional investors, global saving and asset allocation established by the committee on the global financial system.

Curtinn, S. E. (2009). Alternative to Frozen Defined Benefit Pension Plan. US bureau of labour force, 1-18.

Davis, E. P. (2005, March). The role of pension funds as institutional investment in emerging markets. Paper presented at the Korean development institute conference: Population ageing in Korea economic impact and policy issue, Seoul.

Edogbanya, A. (2013). Assessment of the impact of the contributory pension scheme to Nigeria economic development. Global Journal of Management and Business Research, 13(2), 46-59.

Eme, O. I., \& Sam, C. U. (2011). The laws and administration of retirement in Nigeria: A historical approach. Arabian Journal of Business and Management review, 1(2).

Farayibi, A. (2016). The funded pension scheme and economic growth in Nigeria. SSRN Electronic Journal, 10(49), 1-17. doi:10.2139/ssrn.2836965

Fapohunda, T. A. (2013). The Pension system and retirement planning in Nigeria. Mediterranean Journal of Social Sciences, 4(2), 25-34. doi:10.5901/mjss.2013.v4n2p25 
Fashagba, M. O. (2018). Effect of funded pension on the economic growth in Nigeria. Lapai Journal of Management Science, 8(1).

Federal Republic of Nigeria. (2004). Pension reform act. Abuja.

Federal Republic of Nigeria. (2014). Pension reform act. Abuja.

Humphrey, R. W. (1995). Defined benefit versus defined contribution pension plans: How are the interests of employees and the public best served. Employee Responsibilities and Right Journal, 6(1).

Kibet, A. K., \& Simiyu, R. S. (2016). The role of pension scheme in economic: Comparing Kenya and Singapore. Research Journal of Finance and Accounting, 7(16), 161-176.

Lachman, J. (2013). Pension: Its impact on the world economy. International Journal of Business and Commerce, 3(2), 14-25.

Meng, C., \& Pfan, W. D. (2010). The role of pension funds in capital market development. GRIPS Discussion Papers, 10-17, National Graduate Institute for Policy Studies, Minato-ku, Tokyo

Munnell, A. H., Aubry, J., \& Crawford, C. V. (2015). Investment returns: Defined benefit vs. defined contribution plans. Retirement Research.

Neil, A. (1977). Life Contingencies. London, UK: Hennmann.
Nigerian State Pension reform Law. (2015). A New pension scheme in Niger state.

Odia, J. O., \& Okoye, A. E. (2012). Pension reform in Nigeria: A comparison between the old and new schemes. Afro Asian Journal of Social Sciences, 3(3), 1-17.

OECD. (2008). Pension country profile: United Kingdom. Retrieved January 21, 2019, from www.oecd.org/dof/pensions/outlook

Oladipo, J. A., \& Fashagba, M. O. (2012). Evaluation of compliance of the stipulation of the contributory pension scheme: A case study of Quasi Government Institutions in Nigeria. African Research review, 6(4), 5975.

Orenstein, M. I. (2008). Out-liberalizing the EU: pension privatization in Central and Eastern Europe. Journal of European Public Policy, 15(6), 899-917. doi.org/10.1080/13501760802196853

Peifer, C. W. (2015). Adjusting for underfunded pension and postretirement liabilities. Insights, 67-71.

Poterba, J., Rauh, J., Venti, S., \& Wise, D. (2007). Defined contribution plans, defined benefit plans, and accumulation of retirement wealth. Journal of Public Economics, 91(10), 2062-2086. doi:10.1016/j.jpubeco.2007.08.004

Tirimba, O. I. (2013). Role of Pension Funds in Financial Intermediation. International Journal of Finance and Accounting, 2(7), 365-372. doi:10.5923/j.ijfa.20130207.04

Mathew Olasehinde Fashagba is a senior lecturer in Business Administration at Ibbrahim Badamasi Babangida University, Lapai, Niger State, Nigeria. He obtained Ph.D in Business Administration from the University of Ilorin, and teaches courses: Life Contingencies, Operation Research, Business Mathematics, Business Statistics, Financial Management etc. His research interests are on Actuarial science and management.

Emmanuel Olaniyi Dunmade has obtained his Ph.D in Business Administration from Obafemi Awolowo University, Nigeria. He is a member of Chartered Institute of Personnel Management of Nigeria 


\title{
VREDNOVANJE BENEFITA STAROG I NOVOG PENZIJSKOG SISTEMA U NIGERIJI
}

\author{
Mathew Olasehinde Fashagba' and Emmanuel Olaniyi Dunmade ${ }^{2}$ \\ 'Ibrahim Badamasi Babangida University, Lapai, Niger State, Nigeria \\ ${ }^{2}$ Faculty of Management Sciences,University of Ilorin, Ilorin, Nigeria
}

Ova studija ima za cilj da istraži razliku između naknada koje neko lice ostvaruje nakon odlaska u penziju po starom penzijskom režimu, zasnovanog na sistemu tekućeg finansiranja, s jedne strane, i po novom penzijskom sistemu, koji podrazumeva uplatu doprinosa u penzijski fond (CPS), s druge strane. Podaci korišćeni u ovoj studiji su prikupljeni iz sekundarnih izvora. U studiji se primenjuju dve metode: analiza varijanse (ANOVA) i Pearrson-ova korelacija, korišćenjem statističkog paketa za društvene nauke (SPSS) za analizu podataka. Studijom je utvrđeno da je finansijska vrednost naknada po starom penzijskom režimu značajno veća od vrednosti istih po novom penzijskom sistemu, što potvrđuju rezultati sprovedene analize. Studijom je, takođe, utvrđeno da navedene naknade sa aspekta oba penzijska sistema u značajnoj meri slede isti trend. U studiji se zaključuje da se po novom penzijskom sistemu isplaćuje manji iznos penzija u odnosu na stari penzijski režim, u kom smislu se daju preporuke za efikasnije upravljanje investicijama u penzijski fond u cilju ostvarivanja dovoljnog povraćaja kako bi se premostio jaz u pogledu penzijskih primanja koji postoji između ova dva penzijska režima.

Ključne reči: naknada nakon penzionisanja, definisani benefit, definisani doprinos, prihod od penzije

JEL Classification: M21, G20 